\title{
THE GOALS OF ANTITRUST: OTHER THAN COMPETITION AND EFFICIENCY, WHAT ELSE COUNTS?
}

\author{
KeNNETh G. ElZiNGai
}

Whether antitrust policy promotes, or should promote, social goals other than efficiency and competitive markets ${ }^{1}$ deserves some thought because it lies at the root of so much controversy in antitrust. A reading of the congressional debates on the Sherman and Clayton Acts reveals no single thread of efficiency weaving together the whole of the fabric. ${ }^{2}$ The record

† Professor of Economics, University of Virginia. Special Economic Assistant to the Assistant Attorney General, Antitrust Division, 1970-71. B.A. 1963, Kalamazoo College; M.A. 1966, Michigan State University; Ph.D. 1967, Michigan State University.

The helpful comments of William Breit, Robert J. Kroner, Roger Sherman and James E. Meeks are gratefully acknowledged.

An earlier version of this paper was presented at the American Association of Law Schools annual meeting in Houston, Texas, December 29, 1976.

${ }^{1}$ Policies to promote efficiency and policies to promote competitive markets are not necessarily identical. For example, the efficient operation of an industry with declining long-run average costs could not be secured through the structural characteristics of a competitive market. Nonetheless, the theory of perfect competition illuminates the meaning of efficiency, and the two are often used synonymously in common antitrust parlance because, in many instances at least, promoting competitive market conditions is thought to be the same as promoting efficiency. In this paper efficiency is taken as the more inclusive goal, with competitive market prerequisites being a possible means to that end (but not being mandated when they would conflict with this goal). In formulating antitrust policy, securing the goal of economic efficiency might mean stopping short of securing competitive conditions in all markets. See K. Elzinga \& W. B REIT, The ANTItrust Penalties: A Study in Law and Economics (1976).

${ }^{2}$ Hans B. Thorelli has written the most exhaustive treatise on the events leading up to the Sherman Act. H. Thorelli, The Federal Antitrust Policy (1955). Unable to discover a singular congressional intent, Thorelli finally concludes that Congress had a rather untidy mind respecting the Act. Some members were more sincere than others in their desire to end combinations. Some felt the trusts were an unmitigated evil, while others argued that business combinations would have salutary economic effects. The congressional concern with the constitutionality of the proposed bills, with tariffs, and with securing political credit for the enactment, cloud the issue of intent. As Walton Hamilton has put it, "The great bother is that the bill which was arduously debated was never passed, and that the bill which was passed was never really discussed." $W$. Hamilton \& 1. Till, Antitrust in Action (Monograph 16, Temporary National Economic Commitree) 76th Cong., 3d Sess. 11 (1940). Thorelli's conclusion implies that, in the absence of a singleminded legislative intent to pursue efficiency goals, antitrust should manifest concern for other social values.

Robert Bork's inquiry into the debates on the Sherman Act, by contrast, concludes 
does show that efficiency was to be a central goal of antitrust, but not the only one. Consequently, it becomes important to examine the social and political objectives other than efficiency that antitrust enforcement might pursue. What these objectives are, and the extent to which current antitrust policy already reflects them, is the focus of this paper.

\section{Equity and the Goals of the Economists}

Economists sometimes make a rough and ready distinction between the goals of efficiency and equity, and in the case of antitrust policy a useful boundary can be drawn between the two. Efficiency means the maximization of the value of total output. ${ }^{3}$ This value can be maximized only if firms are supplying goods and services in accord with consumer preferences and minimizing production costs in so doing. ${ }^{4}$ By defining efficiency as maximization of total output, the residual political and social goals are easily categorized as equity objectives. Such a dichotomy is tempting, for it leads to the conclusion, held by many trained in law, that these non-efficiency objectives are outside the domain of the economist qua economist." Yet the study of equity objectives has had a long and continuing tradition in those schools of economic thought adhering to the belief that economics has more to offer on equity questions than "one man's opinion" or judgments that bear no relationship to the profession's methods of analysis. ${ }^{6}$

that Congress did have a uniform goal of promoting efficiency, and that antitrust policy" should concern itself solely with that goal, and nothing more. Bork, Legislative Intent and the Policy of the Sherman Act, 9 J.L. \& ECon. 7 (1966). Bork's argument is ingenious and appealing, not only because of the pristine conclusion it reaches. But like King Agrippa after hearing the Apostle Paul, one remains only "almost persuaded."

${ }^{3}$ Technically the maximum includes a value ascribed to leisure.

${ }^{4}$ Economic efficiency does not always square with the term as used in engineering. According to an engineer's specifications, an internal combustion machine may run efficiently with 120 octane fuel at $\mathbf{5} 400$ revolutions per minute. Depending upon relative fuel prices, the economically efficient operation of the engine might involve octane ratings higher or lower than that recommended by the engineer. Economic efficiency involves choosing the cost minimizing technique from among those technologically feasible.

"Much of the important work in the field of law and economics has either taken place at the University of Chicago or appeared in The Journal of Lau and Economics, published at that institution. Because the legal profession's tutelage in economic methodology largely has been in the Chicago tradition, there is need for some corrective instruction regarding the place of equity in "doing economics." By explaining the important difference between positive and normative statements in economics, the Chicago School has performed an enormous service. However, the conclusion that economics qua economics is thereby divorced from equity issues is mischievous.

${ }^{6}$ See, e.g., A. Okun, Equality and Efficiency: The Big Tradeoff (1975). On the 
This tradition is richest concerning the issue of income redistribution. For over a century, beginning with John Stuart Mill and continuing through Henry Sidgwick, Edward Cannan, A.C. Pigou (the father of modern welfare economics), Abba P. Lerner, and the more recent work of Harold M. Hochman and James Rodgers, economists have endeavored to make the case for income redistribution on objective grounds. ${ }^{7}$ In these analyses, the concept of efficiency encompasses the maximization of economic welfare, not just the value of total output, and includes attaining an optimal distribution of income. Equity is central to the analysis. ${ }^{8}$

Once it is perceived that efficiency and equity are not mutually exclusive domains, and that both are susceptible to economic analysis, the nature of their relationship becomes the pertinent inquiry. In some cases economists might find equity and efficiency mutually supportive goals, with an increase in equity producing an increase in efficiency. In other cases, equity objectives might be preferred only so long as they can be attained without sacrificing efficiency. In still other cases, not a few economists might be willing to countenance some finite loss in the real output of goods and services to reach a particular equity objective.

Such alternative approaches are most visible in the treatment of income distribution, the equity consideration that continues to provoke the most attention from economists. The normative bias of the profession, so far as one can discern its majority sentiment, is for a less skewed distribution of income than currently exists in the United States. This is evidenced by the tradition among economists of proposing inheritance taxes, progressive income taxes, negative income taxes, cash transfers, in-kind income supplements, and government employment programs. In addition to income redistribution, there are other areas that have attracted the attention of economists concerned with equity considerations. These include policies favoring: relatively small over relatively large business organizations; private decentralized decision making by incremental change rather

\footnotetext{
historic concern of economics with individual welfare-broadly conceived-see Viner, Adam Smith and Laissez Faire, 35 J. Pol. Econ. 198 (1927).

${ }^{7}$ For a concise survey of this developing tradition, see Breit, Income Redistribution and Efficiency Norms, in Redistribution rhrough Public Choice 3 (1974) (citing authorities).

${ }^{8}$ Similarly, economic theory has become the concern of the philosopher. The tools of the economist are essential to the analysis in the most currently debated work on justice. J. Rawls, A Theory of JUSTICE (1971).
} 
than public centralized decision making by quantum leaps; and economic transactions that are neutral towards minorities. ${ }^{9}$ The relationship of these four equity objectives to antitrust enforcement is the next focus of this inquiry.

\section{Equity and the Pursuit of Efficiency}

\section{A. Redistribution of Income}

The conventional wisdom is that there is a tradeoff between efficiency and income equality. ${ }^{10}$ True, the tack of most economic analysis is to hold the distribution of income constant (or assume it as given) and, from that, to analyze efficiency problems. But no one seriously entertains the notion that some distributions of income, because of their structure of incentives and rewards, will not yield a larger basket of output than others. ${ }^{11}$ As Arthur Okun expressed it in his first Godkin lecture: "We can't have our cake of market efficiency and share it equally." 12

In light of this well-known tradeoff, it is notable that antitrust enforcement generally serves to help those at the low end of the income distribution range without decreasing efficiency. Antitrust achieves this double benefit when it promotes efficiency in resource allocation by preventing the cartelization or monopolization of a market shopped in by low-income buyers. The reason is straightforward: prices will be made lower in this market so that for any given income, however low, a larger basket of goods and services can be purchased. Antitrust policy, therefore, need not concern itself directly with increasing the purchasing power of the poor because it accomplishes this indi-

\footnotetext{
${ }^{9}$ There are a host of other equity objectives that economists might applaud, among them a stable family unit, sound mental health, patriotism, and an end to drug addiction, but that bear only a minimal relationship to antitrust policy.

1" Brehm \& Saving, The Demand for General Assistance Payments, 54 Ам. Econ. Rev. 1002 (1964).

${ }^{11}$ For example, the value of total output will be less with a Gini coefficient of zero than with a coefficient that is (within limits) larger. The Gini coefficient is the ratio of the area bounded by a Lorenz curve and the $45^{\circ}$ line, over the total area under the $45^{\circ}$ line. A Gini coefficient of zero represents perfect equality; coefficients approaching one portray extreme inequality. A Lorenz curve of income distribution plots the percentage of people, ranked by income from lowest to highest, against the percentage of an economy's total income received by these individuals. If income were evenly distributed, the Lorenz curve would be a straight line, $45^{\circ}$ from the origin; an uneven distribution yields a deviation from this ray. The Lorenz curve has also been used to describe industry concentration. See Blair, Statistical Measures of Concentration in Business, 18 BulL. OXFoRd U. INST. OF STATistics 351 (1956).
}

${ }^{12}$ A. OKUn, supra note 6 , at 2. 
rectly when it prohibits cartels and monopolies in the singleminded pursuit of efficiency.

Antitrust actions may not always improve both income distribution and efficiency. For example, the break-up of a cartel of artist-merchants who handcraft porcelain will be efficient, but will bestow its distributional benefits only upon the rich who shop in this market, thus arguably increasing inequality. In most circumstances, however, antitrust gives the efficiency-equality tradeoff the characteristic of having one's cake and eating it too. While a direct assault on inequality through income redistribution might lead to a reduction in efficiency, a direct assault on inefficiency through antitrust will not necessarily result in any reduction in equality. It is far more likely to lead to an actual gain for equality. Lower prices and greater availability of goods for rich and poor alike are not the only equity goals achieved by increasing efficiency. In the long run, more competition will mean less accumulation of wealth from capitalized monopoly positions. Studies suggest that a primary distributional impact of monopoly is its contribution to the wealth holdings of the very affluent. ${ }^{13}$ Over forty percent of the holdings of the wealthiest families has been attributed to the effects of past monopoly. ${ }^{14} \mathrm{Had}$ antitrust been more potent in the past and prevented this wealth accumulation, incomes today would be more evenly distributed without the concomitant efficiency tradeoff that may result if incomes are redistributed directly by government fiat.

In sum, the pursuit of efficiency goals through antitrust enforcement is consistent with the objective of equitable distribution of income. ${ }^{15}$ This is not to say that antitrust policy alone is a sufficient redistributive tool. Most analyses of the poverty problem in the United States attach only minimal importance to inadequate antitrust enforcement as a causative agent. The problem of poverty is attributed more often to the low level of education and job skills of the poor, insufficient aggregate demand,

${ }^{13}$ See, e.g., Comanor \& Smiley, Monopoly and the Distribution of Wealth, 89 Q.J. EcoN. 177 (1975).

${ }^{14} I d$.

${ }_{15}$ Private recovery of treble damages, 15 U.S.C. $\$ 15$ (1970), also has an apparent connection with this equity goal of antitrust. Not only is it supposed to promote equity by compensating the injured from the fruits of an antitrust violation, but it also reduces income inequality if we make the assumption that those who commit violations generally have higher incomes than those they injure. But for a discussion of the overriding inefficiencies attending the treble damage provision, see text accompanying notes 63-71 infra. 
the distorted incentives of current welfare policies, drug addiction and alcoholism, racial discrimination, and a cognitive present orientation among the poor that cuts against exchanging present for future satisfaction. ${ }^{16}$ Thus, the pursuit of egalitarian income distribution through antitrust enforcement is likely to have limited results. In fact, antitrust pursuit of equity goals is foreclosed in some areas. For example, those "restraints of trade" effected by labor unions and minimum wage laws directly contribute to income maldistribution, but, with only a few exceptions, antitrust is unable to strike at labor market restraints. ${ }^{17}$

\section{B. Promotion of Small Business Enterprise}

The preference for small rather than large business units would appear to be an ideal candidate for an antitrust equity goal and one readily achieved through a strict policy against mergers and the more frequent use of dissolution decrees. Yet here too antitrust has a limited role to play. A merger policy that is too strict hurts small business, a point not always understood even by the friends of small business. Should the small enterprise suffer financial reverses, or should aging owners wish to sell out, the number of potential buyers will be minimized by a merger policy that is too severe. This means the possibility of running afoul of such an antimerger policy becomes an added risk of entering the market. The result could be fewer small businesses, just the opposite of what is desired.

Wholesale dissolution of firms that dominate their industries would reduce concentration and work to achieve the small business equity objective. Yet economists increasingly recognize that the use of this remedy results in a major efficiency loss. Paradoxically, only the infrequent use of structural relief may preserve the weapon's potency. If, through enactment of the Hart bill, ${ }^{18}$ or a dissolution precedent arising from such cases as United States

${ }^{16}$ See Lampman, Approaches to the Reduction of Poverty, 55 Am. Econ. Rev. 521, 524-25 (1965). See generally E. Banfield, The UnheAvenly City (1968).

${ }^{17}$ In Apex Hosiery Co. 7. Leader, 310 U.S. 469 (1940), the Sherman Act was held not to apply to "restraints on the sale of the employee's services to the employer." Id. at 503. See also United States v. Hutcheson, 312 U.S. 219 (1941). The broad union exemption under Apex Hosien has been narrowed recently in Connell Constr. Co. v. Plumbers Local 100, 421 U.S. 616 (1975). Antitrust has also made important inroads on restaints upon competition by professional associations. E.g., Goldfarb v. Virginia State Bar, 421 U.S. 773 (1975).

${ }^{18}$ The Industrial Reorganization Act: Hearings on S. 1167 Before the Subcomm. on Antitrust E Monopoly of the Senate Comm. an the Judiciary, 93d Cong., lst Sess. 3-34 (1973). 
7. International Business Machines, Inc., ${ }^{19}$ In re Exxon Corp. ${ }^{20}$ or In re Kellogg Co., ${ }^{21}$ structural relief is prescribed as standard relief in concentrated industries, any merits the remedy might have had will become very difficult to sustain. ${ }^{22}$

The dissolution of conglomerate firms, like the antitrust attack on concentration within one industry, would help to secure the equity objective of more firms and reductions in aggregate concentration. But here too, the efficiency costs must be considered. Conglomerates are said to confer benefits because of both the synergy effect unavailable to more specialized firms and the superiority of the allocation of financial resources within the firm, compared to the allocation externally imposed by the capital market. Neither claim is wholly persuasive. The most probable virtues of the conglomerate form of business organization are its facilitation of mergers, thus easing entry into markets, and its role in encouraging takeover threats, thus promoting managerial efficiency. ${ }^{23}$

Even if there are efficiency gains from conglomerate firms, these benefits must be balanced against the potential that the mastodonic conglomerate has for obtaining anticompetitive advantages and special favors from the government. The point is not always appreciated that small enterprises, located in but one congressional district and without a potent trade association, cannot marshal the forces of a large, diversified firm with facilities in over a hundred districts. It is sobering to consider that one of the most frequent changes made by conglomerates in the administration of formerly independent firms that they have acquired is to provide new legal counsel so that the companies have better Washington representation.

The phenomenon of conglomeration is beyond the pale of economic theory, but at least potentially cognizable by antitrust law. ${ }^{24}$ The O.M. Scott grass seed company presents a simple example. Until recently, it was an independent firm with a sig-

\footnotetext{
${ }^{19}$ Civ. No. 69-200 (S.D.N.Y., filed Jan. 17, 1969).

${ }^{20}$ No. 8934 (FTC, filed Sept. 17, 1973).

${ }^{21}$ No. 8883 (FTC, filed May 4, 1972).

22 See K. ElziNGA \& W. B REIT, supra note 1, at 97-111.

${ }^{23}$ Either of these benefits could also be secured if the law on horizontal or vertical mergers were not so surict.

${ }^{24}$ Clayton Act $\$ 7,15$ U.S.C. $\$ 18$ (1970) bans mergers "where . . . the effect of such acquisition may be substantially to lessen competition, or to tend to create a monopoly." The Supreme Court has explicitly held that conglomerate mergers are within the reach of $\S 7$. FTC v. Procter \& Gamble Co., 386 U.S. 568, 577 \& n.2 (1967).
} 
nificant but not dominant share of the grass seed industry. Then Scott was acquired by ITT. Within the confines of economic theory, nothing has happened. The merger is of the pure conglomerate variety since ITT was not in the grass seed business before the merger. Thus, after the acquistion, ITT-Scott has no greater share of the grass seed business, and theoretically no more control over prices, than Scott had previously. There appears to be no incremental gain in market power. Dr. Morris Adelman summed up the conventional wisdom neatly: “. . . [the] absolute size [of a company] is absolutely irrelevant." ${ }^{25}$ Yet mergers of no seeming economic consequence may have significant effects on the antitrust equity goal of promoting small business. The Scott seed company, under the aegis of ITT, may find that the federal government is far more approachable than it ever was when Scott was independent. Scott may be more likely to use this new position to gain favors regarding taxes, import competition, government contracts, and other amenities which will give it an advantage over its rivals and thereby lessen competition in the grass seed industry. ${ }^{26}$

It requires a certain temerity to recommend the wholesale dissolution of large conglomerates in order to achieve a more Jeffersonian business landscape. This is especially true since so little is known about the costs-economic and social-of implementing dissolution orders. To demonstrate unequivocally that the administrative costs of structural relief and the psychic costs paid by affected personnel will not outweigh the equity advantages of having an additional number of firms is a substantial task, even for an ardent populist. Yet if the object is increasing the number of independent business units, plucking divisions from a conglomerate firm, or separating a newly merged business, will effect less of an efficiency loss, in most cases, than outright horizontal dissolution of a concentrated industry. ${ }^{27}$

${ }^{25}$ Hearings on Economic Concentration Before the Subcomm. on Antitust \& Monopoly of the Senate Comm. on the Judiciary, 88th Cong., 2d Sess. 228 (1964) (remarks of Morris A. Adelman).

${ }^{26}$ In fairness let it be said that some small companies also have been adroit in securing favors from the state. The exemption which hog cholera serum producers have received from the antitrust laws is only one example. 7 U.S.C. $\$ 852$ (1970). But social policy must be built on probabilities. And in overall capacity, small or medium size companies can rarely match the resources of a corporate leviathan in seeking government bestowed advantages.

${ }^{27}$ Outright dissolution of any large firm would tend to increase the number of smaller firms. This equity gain would be achieved only at considerable efficiency loss, at 
Breaking a firm into units that will themselves be in the same industry requires much more exhaustive analysis to ascertain whether gains in equity will be offset by losses in business efficiency, adverse incentive effects on management to compete, and the economic costs of accomplishing the dissolution. ${ }^{28}$

Antitrust provisions that deal with a firm's marketing conduct, such as the bans on price fixing, ${ }^{29}$ "tying," ${ }^{30}$ and restricting its dealers, ${ }^{31}$ may affect the prospects for small business as much as does merger policy. No blanket, a priori answer can be given respecting the effect restrictions on these practices have on small businesses. Rules against price discrimination can render more difficult the entry into new markets by a firm of any size, as can prohibitions against tying. The long debated and extensively lobbied bill to exempt soft drink bottlers from the rule of United States \%. Amold, Schwinn $E \mathrm{Co}^{32}$ is promoted by its backers as aiding small bottlers. No doubt some bottlers will be assisted, but the current restriction of territorial expansion is likewise harmful to the efficient bottler who has both a small territory and growth aspirations.

As in the case of income redistribution, antitrust enforce-

least in terms of the diseconomy of the dismantling process itself. See text accompanying notes 18-22 supra. This diseconomy is appreciably less severe in the case of a conglomerate dissolution.

${ }^{28}$ A recent circuit court decision illustrates the complexities of trying explicitly to promote small business through antitrust enforcement. The majority opinion concluded that a certain vertical market restriction was permissible under the Sherman Act, in part because it would generate and promote small business enterprise. GTE Sylvania Inc. v. Continental T.V. Inc., 537 F.2d 980, 999-1000 (9th Cir.), cert. granted, 97 S. Ct. 252 (1976). The dissent, with an apparent equal concern for small-firm equity, argued that the vertical restaint limited the choices of some existing small firms and therefore ran afoul of the Sherman Act. Id. at 1018-19, 1025-26. The tension between validating alleged antitrust violations to ensure survival of small business in competition with larger chains, at the expense of competition among the smaller firms, is an oftenrepeated theme in antitrust law. See, e.g., United States v. Topco Assocs., 405 U.S. 596, 610-11 (1972) (horizontal exclusive territory agreement among smaller firms violates Sherman Act \$ 1).

${ }^{29}$ Clayton Act $\S 2,15$ U.S.C. $§ 13$ (1970); see Robinson-Patman Act $\$ 3,15$ U.S.C. $\S 13(a)(1970)$.

${ }^{30}$ See Clayton Act \& 3, 15 U.S.C. \$ 14 (1970).

${ }^{31}$ See United States v. Arnold, Schwinn \& Co., 388 U.S. 365 (1967); White Motor Co. v. United States, 372 U.S. 253 (1963).

32388 U.S. 365 (1967). Schwinn held that "[u]nder the Sherman Act, it is unreasonable without more for a manufacturer to seek to restrict and confine areas or persons with whom an article may be traded after the manufacturer has parted with dominion over it." Id. at 379 . The Court did not "prohibit all vertical restrictions of territory and all franchising, in the sense of designating specified distributors and retailers as the chosen instruments through which the manufacturer, retaining ownership of the goods, will distribute them to the public." Id. at 379-80. 
ment is consistent with the equity preference for small business and a reduction in aggregate concentration. Particularly, antimerger enforcement in the case of conglomeration would unite the equity goal with minimal diseconomy. Elsewhere, however, any beneficial effect of enforcement on small business enterprise becomes speculative, and the efficiency tradeoff more noticeable. A high level of aggregate demand, a stable price level, a revision in the corporate tax policy, or all three would contribute more to the prospects for small business and the achievement of this equity objective than antimerger cases or dissolution decrees.

\section{Promotion of the Liberty of the Entrepreneur}

The equity bias in favor of private decentralized decisionmaking is grounded in a preference for the individual's freedom from excessive government control and experimentation. Friedrich $\mathrm{A}$. Hayek and Milton Friedman, among others, have argued the intractable relationship between individual freedom and a competitive market economy. ${ }^{33}$ Although antitrust enforcement directed at maintaining competitive markets generally makes a positive contribution toward freedom from government control, there are also instances in which liberty and efficiency become competing, rather than mutually supportive, interests of antitrust:

There are three principal points at which antitrust may conflict with the equity objective of freedom from government controls. The first type of conflict arises when the promotion of efficiency through the antitrust laws proceeds along principles so uncertain, and in directions so unpredictable, as to exert a chilling effect on legitimate business enterprise. ${ }^{34}$

The second potential conflict arises when injunctive relief of such complexity is entered against defendant firms that the Government becomes involved in the day-to-day operations of the companies themselves. In his classic article on antitrust standards, A. E. Kahn argued that such activity is inconsistent with the concept of antitrust: "The antitrust laws involve the Government in no entrepreneurial activity proper and require no detailed review of either basic investment commitments or run-

\footnotetext{
${ }^{33}$ F.A. Hayek, The Road to Serfdom (1945); M. Friedman, Capitalism and FrEEDOM (1962).

${ }^{34}$ An example of current interest is the confused question of the antitrust plaintiff's standing. See, e.g., Sherman, Antitrust Standing: From Loeb to Malamud, 51 N.Y.U.L. Rev. 374 (1976); text accompanying note 71 infra.
} 
of-the-mill business decisions."35 The movie industry decrees, which once occupied many members of the Antitrust Division's staff in compliance efforts, were a notable example of a distortion of the antitrust concept which in turn violated this equity objective. $^{36}$

The third and most serious conflict between the objectives of efficiency and liberty arises when the ban of the antitrust law is withheld from unabashedly anticompetitive behavior to secure constitutional values similar to, but broader than, the asserted right of the individual to transact business free from unnecessary governmental interference. For example, Parker $\%$. Brown ${ }^{37}$ held that a patently anticompetitive raisin marketing scheme implemented by state law was a valid state regulation of a local economic activity, not constitutionally pre-empted by the commerce clause. The state regulation did not violate the Sherman Act, which "makes no mention of the state as such, and gives no hint that it was intended to restrain state action or official action directed by a state." 38 Such an antitrust exemption plainly sacrifices the efficiency goal to vindicate the overriding noneconomic equity value of federalism. Similarly, Eastern Railroad Presidents Conference t'. Noerr Motor Freight, Inc. ${ }^{39}$ decided that the Sherman Act did not prohibit a combination attempting to influence state legislation that allegedly would produce a monopoly or restraint of trade. The consequent diseconomy has been considered the tolerable cost of protecting the constitutional right of business to petition the government and of preserving the state regulatory power addressed in Parker. ${ }^{40}$ The Solomon of antitrust has yet to appear who can harmonize the equity goals promoted in Parker and Noerr with the efficiency objective of antitrust enforcement.

${ }^{35}$ Kahn, Standards for Antitrust Policy, 67 HARv. L. REv. 28, 30 (1953).

${ }^{36}$ Continuing regulation of copyright licensors, pursuant to antitrust consent decrees, provides another example of antitrust intrusion into a defendant firm's internal workings. See Hearings on Policies of American Society of Composers, Authars, \& Publishers, Before Subcomm. No. 5 of the House Select Comm. on Small Business, 85th Cong., 2d Sess. 138-4l (1958) (statement of Victor R. Hansen).

37317 U.S. 341 (1943). For a recent delimitation of Parker, see Cantor v. Detroit Edison Co., 96 S. Ct. 3110 (1976).

${ }^{38} 317$ U.S. at 351.

39365 U.S. 127 (1961). See United Mine Workers of America v. Pennington, 381 U.S. $657,669-72$ (1965). The Noerr-Pennington doctrine has been limited, with the general concurrence of economists. Otter Tail Power Co. v. United States, 410 U.S. 366 (1973); California Motor Transp. Co. v. Trucking Unlimited, 404 U.S. 508 (1972).

${ }^{40}$ See 365 U.S. at $137-38 \&$ n.17. 
Yet antitrust enforcement, unlike other forms of government interference, is basically compatible with the liberty of the entrepreneur because of its philosophy of promoting competitive markets. The current extraordinary interest in Citizens Band (CB) radios is a telling example of the market's ability to smoothly adapt to changing circumstances. The popularity of this product had not been forecast in either astrology charts or econometric models. Yet the market has adjusted rather smoothly to meet the demand and, should the fad peter out, likely will contract without cataclysm. The only bottleneck that exists is obtaining the requisite government license. One need not be a free market ideologue to predict that if the market system provided the licenses, and the FCC produced CB radios, the locus of the bottleneck would be exactly reversed.

\section{Neutral Treatment of Minorities}

In the desire to achieve equity in race relations, antitrust also can make a positive contribution. But, as with income redistribution, the economic theory of discrimination suggests that the tactic antitrust should take is to "ignore" the issue and concentrate on promoting efficiency and competitive markets. In doing so, as if by an invisible hand, the amount of discrimination in economic transactions will be reduced for, ceteris paribus, there will be more racial discrimination associated with a regulated firm than with an unregulated one, and more associated with a monopoly than with a competitive firm. ${ }^{41}$ Proponents of racial neutrality should support the antitrust criterion of efficiency and competitive markets and its expansion into other areas of the economy.

\section{E. Conclusion}

Equity goals, such as a more egalitarian distribution of income and the deterrence of racial discrimination, are indirectly and costlessly promoted by a direct attack on inefficient, anticompetitive market structures and practices. Even where antitrust can make only a modest or unmeasurable contribution to nonefficiency objectives, the lack of numerous intractable conflicts between efficiency and the equity objectives discussed is

${ }^{41}$ G. Becker, The Economics of Discrimination 40 (1957); T. Sowell, Race and Economics (1975); Alchian \& Kessel, Competition, Monopoly, and the Pursuit of Money, in Aspecrs of LABOR ECONOMICS 157-75 (1962); Shepherd, Market Power and Racial Discrimination in White-Collar Employment, 14 ANTITRusr Bull. 141 (1969). 
both notable and congenial. Economic policy normally is a matter of tradeoffs, hard choices where benefits come only with significant costs attached. Conceptually at least, antitrust policy represents an exception to this general rule. It remains, then, to review the relationship between current antitrust policies and the desired objectives.

\section{Equity and Present Antitrust Policy}

\section{A. The Stated Purposes of Antitnist Enforcement}

The extent to which prevailing antitrust case law and enforcement directives have come to internalize non-efficiency objectives is a double-barreled question. One must examine not only what the authorities state as goals but also the effects of the actions they take. The first barrel of the question can be best answered by legal scholars, ${ }^{42}$ although even economists who browse through legal opinions are acquainted with statements bearing on this issue. One of the most familiar is Judge Learned Hand's assertion in United States 1'. Aluminum Co. of America: ${ }^{\mathbf{4 3}}$

[Congress in passing the Sherman Act] was not necessarily actuated by economic motives alone. It is possible, because of its indirect social or moral effect, to prefer a system of small producers, each dependent for his success upon his own skill and character, to one in which the great mass of those engaged must accept the direction of a few. ${ }^{44}$

Chief Justice Warren's juxtaposition of contradictory sentences in Broum Shoe Co. '1. United States ${ }^{45}$ is also well known:

It is competition, not competitors, which the Act protects. But we cannot fail to recognize Congress' desire to promote competition through the protection of viable, small, locally owned businesses. Congress appreciated that occasional higher costs and prices might result from the maintenance of fragmented industries and markets. ${ }^{46}$

12 See, e.g., Kauper, The "Warren Court" and the Antitrust Lau's: of Economics, Populism, and Cynicism, 67 MrCH. L. Rev. 325 (1968).

43148 F.2d 416 (1945).

${ }^{4} I d$. at 427.

45370 U.S. 294 (1962).

${ }^{46} I d$. at 344 . 
Cases such as United States '1. Von's Grocery Co. ${ }^{47}$ and United States v. G. Heileman Brewing Co., ${ }^{48}$ brought by the Justice Department, and a plethora of actions brought by the Federal Trade Commission under the Robinson-Patman Act show a sympathy for the objective of preserving small business units, even if this involves some loss of efficiency or competitive fervor.

Yet, so far as stated intentions go, government antitrust enforcement has not roamed very far in the pursuit of nonefficiency objectives. Apart from the objective of preserving small business, for which respectable economic opinion argues there may be little, if any, tradeoff against efficiency, ${ }^{49}$ the judiciary and the enforcement agencies would make it seem that efficiency is their only goal.

\section{B. The Effects of Antitrist Enforcement}

\section{The Substantive Law}

The actual record of antitrust, statements about it aside, does not lend itself to ready summary. Consider, for example, two practices where the law seems clearest: price-fixing and tying. The restrictions on each are stringent and well known. The per se prohibition of price-fixing ${ }^{50}$ represents a clear victory for the efficiency objective as it requires some fancy footwork to argue that horizontal price fixing would ever increase the value of total output. The Supreme Court once flirted with an equity perspective that allowed the survival of a beleaguered conspiracy of coal firms, ${ }^{51}$ but that decision did not survive the end of the depression and would be cited today in defense of a cartel only by a novice attorney.

In the case of tying, conversely, the courts have banished ${ }^{52}$ a practice that is often efficient. ${ }^{53}$ The successful transfer of a monopoly position from one market to another by tying ar-

47384 U.S. 270 (1966).

48 345 F. Supp. 117 (E.D. Mich. 1972).

${ }^{49}$ E.g., Adams, Is Bigness a Crime?, 27 Land Ecos. 287 (1951).

s" See, e.g., United States v. Socony-Vacuum Oil Co., 310 U.S. 150 (1940).

51 Appalachian Coals, Inc. v. United States, 288 U.S. 344 (1933).

52 See, e.g., Fortner Enterprises, Inc. v. United States Steel Corp., 394 U.S. 495 (1969); International Salt Co. v. United States, 332 U.S. 392 (1947). "Tying" is the practice of selling goods on the condition that the customer buy other products from the seller.

${ }_{53}$ Markovits, Tie-Ins, Leterage, and the American Antitrust Lauts, 80 YALE L. J. 195 (1970). 
rangements would be a remarkable achievement. In the absence of price controls on the tying good or a concern with quality control in the interaction of the tied and tying products, the principal rationale for a firm to tie is to price discriminate between customers. ${ }^{54}$ The different profit returns this provides on the tied good may yield a higher total profit than a single monopoly price for the tying good. In such a case, tying could cause, in addition to greater profits, a larger (and more efficient) rate of output for the monopolized tying good. Yet the language with which tying has been condemned has not reflected equity objectives. The opinions read as if tying is always a monopolistic problem. Whether the authorities misconstrue the economic effects of the business practice they are restricting or else hold an unstated equity objection to tying is a question for practitioners of legal realism. By Occam's razor, the more likely hypothesis is that the antitrust authorities have misunderstood the economics of tying. Merger cases strike an uncertain balance between efficiency and equity. The efficiency case for a strong law against merger is clear: mergers have been a favorite route to market power, resource misallocation, and attendant reductions in the value of total output. But in some industries, for example, brewing, dairies, and grocery retailing, the enforcement may have become so strict as to work a hardship on small business, thereby running counter to the equity objective and yielding in return very little positive effect on efficiency. Moreover, in the formation of relief decrees, the equity objective of augmenting the number of independent firms seems to have had minor effects. There has been little divestiture under section $7^{55}$ that has resulted in the restoration to the marketplace of new independent centers of initiative.

The Robinson-Patman Act is an antitrust statute almost explicitly ordained to carry the equity burden of promoting small business. Yet lawyers and members of the bench have shown the internal contradictions and abiding unpredictability of the enforcement process. ${ }^{56}$ Moreover, economists, even those who have

${ }^{54}$ See Bowman, Tying Arrangements and the Leterage Problem, 67 YALE L.J. 19, 23 (1957). Other purposes of tying include attempts to monopolize and to disguise prices. See generally Burstein, $A$ Theory of Full-Line Forcing, 55 Nw. U.L. Rev. 62 (1960).

${ }_{55}$ Clayton Act $\$ 7,15$ U.S.C. $\$ 18$ (1970).

${ }^{56}$ U.S. Dept. of Justice, Report on the Robinson-Patman ACt (1977); Elias, Robinson-Patman: Time for Rechiseling, 26 MERCER L. REv. 689, 689-90 (1975) (citing authorities). 
a bias in favor of small business, generally are able to restrain their enthusiasm for this Act. Such criticism reflects the doubt, engendered by economic theory and the empirical studies of predatory pricing, that price discrimination is a serious anticompetitive problem causing efficiency losses. ${ }^{57}$ The clincher is that small business, if less efficient than its larger counterparts, could be protected at less cost by tax policies favorable to it than by the preservation of artificial price differentials sustained by the Robinson-Patman Act. ${ }^{58}$

The enforcement of the anti-monopolization provision of section 2 of the Sherman Act evidences a far greater concern with efficiency than with equity objectives. Despite Judge Hand's allusion to the noneconomic objectives of the Act, ${ }^{59}$ Alcoa preserves the efficiency-related defenses of a single firm, however dominant a market share it may enjoy. ${ }^{60}$ These defenses have reappeared, in revised fashion, in United States 7 . Grinnell Corp. ${ }^{61}$ The post World War II period has produced few monopoly cases, and a more definitive assessment awaits the Supreme Court's decision in $I B M$, should such an eschatological event occur.

\section{The Private Action}

The future need not be waited upon to observe the efficiency and equity effects of antitrust's growth industry, the pri-

${ }^{57}$ Elzinga, Predatory Pricing: The Case of the Gunpowder Trust, 13 J.L. \& Econ. 223 (1970); Koller, The Myth of Predatory Pricing: An Empirical Survey, 4 ANTITrust L. \& ECoN. Rev. 105 (1971); McGee, Predatory Price Cutting: The Standard Oil (N.J.) Case, 1 J.L. \& Econ. 137 (1958); Telser, Cutthroat Competition and the Long-Purse, 9 J.L. \& Ecos. 255 (1966).

${ }_{58}$ The perverse effect of current federal tax policies has been described by Milton Friedman. M. FRIEDMAN, supra note 33, at 130. For a careful elaboration of how tax policies promote conglomerate bigness, see Sherman, How Tax Policy Induces Conglomerate Mergers, 25 NaT'L TAX J. 521 (1972).

5. Text accompanying note 44 supra.

6I A market may, for example, be so limited that it is impossible to produce at all and meet the cost of production except by a plant large enough to supply the whole demand. Or there may be changes in taste or in cost which drive out all but one purveyor. A single producer may be the survivor out of a group of active competitors, merely by virtue of his superior skill, foresight and industry. In such cases a strong argument can be made that, although, the result may expose the public to the evils of monopoly, the Act does not mean to condemn the resultant of those very forces which it is its prime object to foster: finis opus coronat.

148 F.2d at 430.

${ }^{61} 384$ U.S. 563, $570-71$ (1966). 
vate treble damage action. ${ }^{62}$ Here, antitrust presents a significant departure from both efficiency and equity. There are, of course, three basic options for enforcing the antitrust laws: (1) to have the antitrust weapons solely in the hands of the government, ${ }^{63}$ (2) to have these instruments wielded only by private individuals, ${ }^{64}$ and (3) the current situation, widely applauded, in which the Justice Department, the Federal Trade Commission, and private plaintiffs may enforce the antitrust laws.

The economic approach is to adopt the first option. For years teachers of economics have used national defense as an example of a pure public good. Antitrust could just as well be cited for its benefits are both non-excludable and indivisible. If one person enjoys the services of a market made competitive by antitrust, this does not preclude others from that enjoyment, nor would it be economical to exclude others. The mere existence of a public good does not mean the government must provide it, ${ }^{65}$ but elementary principles demonstrate the difficulties of pricing public goods through the market by affording a private right of action. ${ }^{66}$

Crucial to an examination of private actions is the understanding that antitrust defendants are not the only source of inefficiency. Private enforcers may also cause misallocation of resources. First, the prospect of recovering treble damages may cause the injured party to submit to an antitrust violation rather than rationally to seek competitive substitutes. ${ }^{67}$ Second, suits brought for "nuisance" value, with their attendant costs, may be encouraged by uncertainty in the law, capricious damage awards, and the consequent willingness of antitrust defendants to settle unfounded actions out of court. ${ }^{68}$ Third, affording damages to private plaintiffs creates transaction costs of administering such reparations, which are not associated with public enforcement. ${ }^{69}$

62 Clayton Act $\S 4,15$ U.S.C. § 15 (1970).

${ }^{63}$ This position was taken by trust buster Thurman Arnold. See T. Arnold, The BOTTLENECKS OF Business 166 (1940).

64 This position is held by some members of the Chicago school. See Becker \& Stigler, Law Enforcement, Malfeasance, and Compensation of Enforcers, 3 J. LEGAL STUD. 1, 14 (1974).

${ }^{65}$ See J. Buchanan, The Demand and Supply of Public Goods, 171-90 (1968).

${ }^{66}$ R. McKean, Public Spending $72-75$ (1968).

${ }^{67}$ Breit \& Elzinga, Antitmust Enforcement and Economic Efficiency: The Uneasy Case for Treble Damages, 17 J. LAw \& Econ. 329, 335-40 (1974).

G8 $340-44$.

69. Id. 344 . 
Proposals to abate any of these disadvantages of the private suit can never embrace all of the inefficiencies, and attempts to ameliorate one can exacerbate another. Because both antitrust plaintiffs and defendants are in a position to mitigate inefficiency, the efficient policy is to have an arrangement by which both parties to a transaction share liability. ${ }^{70}$ Both buyers and sellers must be affected. Enacting such a plan would mean ending the award of damages to a monopolist's customers, thus eliminating the three inefficiencies of private enforcement. The seller would also be penalized enough to cause him to abandon, or never to begin, the anticompetitive activity.

But, it could be argued, what of the equity advantages of private actions? Is it not fair, even if relatively inefficient, that those damaged by monopolistic activities be the beneficiaries of restitution by the perpetrators? Yet efficiency and equity are inconsistent goals, in this context, only to the extent that treble damage payments actually compensate those damaged by monopolistic activities. ${ }^{71}$ Even with no empirical investigation of the topic, economic theory indicates at the outset that the laudable goal of full restitution is impossible. The theory of monopoly demonstrates that the welfare loss to consumers caused by monopoly is greater than the profits of the monopolist. It is not only impossible to squeeze treble damages out of the profits reaped from monopolistic power; full and complete single damages to everyone injured in fact are often unavailable.

In the actual awarding of "damages" there is currently only the roughest equivalence between those who are actually damaged and those who are compensated. There are individuals, clearly singled out by economic theory as damaged in some amount, to whom the courts have not granted standing. An obvious example is the person who, because of a monopolistic price, does not buy the product but who would have purchased

70 This follows from the "Coase Theorem." Coase, The Problem of Social Cost, $3 \mathrm{~J}$. LAw \& ECON. 1 (1960). The richness of this contribution is perhaps best evidenced by the sizable literature the article has spawned. The theorem, which was not designated as such by Coase himself, is that in a world of neither transaction costs nor free riders, the final composition of output (and therefore efficiency) is unaffected by the assignment of rules of liability. In our case, antitrust plaintiffs as well as defendants are in a position to avoid the costs of the violation. Thus, both can be made to bear the responsibility to do so, without affecting the resulting measure of efficiency.

${ }^{71}$ See Breit \& Elzinga, supra note 67; Wheeler, Antitrust Treble-Damage Actions: Do They Work? 61 CALIF. L. REv. 1319 (1973) (answering in the negative). 
some quantity at a competitive price. Ironically, an actual buyer, who might still be receiving some consumer's surplus through transactions in the monopolized market, is eligible for damages; the non-buyer, who has just as clearly been harmed, is not. While tracing the correspondence between actual losers from anticompetitive activity and the actual beneficiaries of treble damage payments is not an easy task, impressionistic evidence indicates that the prime beneficiary of the restitution that does take place is the antitrust bar.

The conundrum of how equitably to compensate the losers from anticompetitive markets is ultimately an economic one. Economists do not currently possess a precise understanding of the full incidence of monopoly. The issue is as complex as sorting out the true incidence of a tax. What is clear is that monopoly is inefficient; it leads to the production of too few of some goods and too many of others with a net effect of reducing the value of total output. Yet isolating the damaged individuals and the exact amount of their losses is a matter involving some speculation. Until a breakthrough in economic analysis and the rationalization of standing rules place the equity goal of compensating the injured within reach, it should be conceded that the present private action provision strikes a pernicious balance between the undoubted merits of efficiency and the uncertain equity of private reparation.

\section{Efficiency as a Useful Antitrust Objective}

Economists are fascinated with lags. Predicting the precise lag between a change in fiscal policy and its effect upon the gross national product can win an economist much fame, and even more fortune. There are lags in academics as well. Once some members of the legal profession acquainted themselves with neoclassical economic analysis, it was inevitable that only later would they discover criticisms of the paradigm. This is now occurring, with the resultant assertions that efficiency and the related paraphernalia in the economist's tool kit are hardly adquate to inform our policy choices.

The most trenchant criticisms yet made of conventional economic theory, those of the Institutionalists, remain undiscovered by jurists. ${ }^{72}$ Instead, the critics charge that economic theory is tautological, and that in any event the pursuit of effi-

${ }^{72}$ C. Ayres, The Theory of Economic Progress (2d ed. 1962). 
ciency has been rendered hopeless by the theory of second-best. The first charge is simply in error and easily corrected by reference to most any price theory book. ${ }^{73}$ The second critique, based on second-best, deserves further investigation. ${ }^{74}$

Professors Arthur Leff and Lawrence Sullivan provide convenient and accessible examples of the latter charge. ${ }^{75}$ While Sullivan provides the more recondite scholarship, Leff has the virtue of humor. He summarizes second-best simply: "If a state of affairs is the product of $n$ variables, and you have knowledge of or control over less than $n$ variables, if you think you know what's going to happen when you vary your variables, you're a booby."76 Sullivan goes further: after denominating economic theory as "useless," he explains that the standard analytical constructs of economics can offer no efficiency guidelines except under very extreme conditions. "Since the real world never meets these theoretical presuppositions, the theory simply gives no guidance for improving real world allocations. . . . Any economist conversant with the basic tenants [sic] of welfare theory will support [this]." 77

Bold statements always have appeal, even when they are incorrect, as these are. Professor Sullivan's assessment of economic theory is mistaken; his polling of economists apparently did not follow a sound sampling procedure.

In too few words, the theory of second-best ordains that in a world not meeting the efficiency ideal of all prices equated with marginal costs, the movement to equality in one market, perhaps due to an antitrust action, could reduce instead of improve efficiency. Since many markets in the United States economy do not have prices equal to marginal costs, if an antitrust action equalized price with marginal cost in one market, this purportedly might reduce the overall value of total output. At the outset this might seem to be a serious weakness of antitrust as a viable social institution for promoting efficiency and the concomitant equity objectives. Yet for several reasons the second

${ }^{73}$ E.g., G. Stigler, The Theory of Price 1-10 (3d ed. 1966).

${ }^{74}$ The original formulation of second-best was in J. MEADE, 2 The THEORY of International Economic Policy: Trade and Welfare 102-18 (1955). The more formal exposition of the theory appeared in Lipsey, The General Theory of Second Best, 24 Rev. ECon. Srud. 11 (1956).

${ }^{75}$ Leff, Economic Analysis of Law: Some Realism about Nominalism, 60 VA. L. Rev. 451 (1974); Sullivan, Book Review, 75 Colum. L. Rev. 1214 (1975).

${ }^{76}$ Leff, supra note 75 , at 476.

${ }^{77}$ Sullivan, supra note 75, at 1220. 
best attack is only a surface one. First, the theory of second-best does not limit, demean or negate the benefits of efficiency in resource allocation. It only implies that promoting efficiency is a complex problem. Second, without gainsaying the theory's formal contribution, its application has been confined to very few areas. ${ }^{78}$ Third, for a purist on the efficiency objective, secondbest poses no obstacle because the way to the ultimate objective of first-best is through policies that, market by market and industry by industry if necessary, accomplish that end.

There is another reason to cloak economic inquiry in neoclassical, partial equilibrium analysis. It works. It not only has its own logical consistency, but economists repeatedly have found that it does enable verifiable predictions to be made about the real world. For example, if a sufficiently high minimum wage is legislated in the United States, conventional economic theory predicts that unemployment will result. The theory of secondbest would hold that unemployment could be worsened, improved, or even unaffected. But study after study has found rising unemployment predictably and consistently associated with minimum wage laws. A bread cartel is formed in Seattle. The conventional models of competition and monopoly predict that prices will increase. This is what happened. Later the cartel is discovered and deterred by antitrust action. The same models predict a price decrease. This, too, is what actually occurred. The theory of second best would offer no such predictions. Should any legal pragmatist be surprised, then, that most economists select the neoclassical paradigm?

That the real world does not correlate to the theoretical presuppositions of economic theory, while undoubtedly true, does not vitiate the usefulness of the paradigm. Imagine that somehow the principles of physics were believed to have applicability to the study of law. Would a jurist argue that the lessons of physics should still not be considered because physicists are continuously assuming such "unrealistic" presuppositions as

78 Tibor Scitovsky observes that second-best has been applied successfully only in problems of international trade. T. ScITovSKY, WELFARE AND COMPETITION 481 (rev. ed. 1971). Cf. United States Postal Rate Comm'n Docket No. R74-1, Postal Rate and FEE INCREASES, 1973 (1973) (adopting second-best considerations). For futher delimitation of the scope of second-best, see Davis \& Whinston, Piecemeal Policy in the Theory of Second Best, 34 Rev. Econ. Stud. 323 (1967); Davis \& Whinston, Externalities, Welfare, and the Theory of Games, $70 \mathrm{~J}$. PoL. Econ. 241 (1962); McManus, Prinate and Social Costs in the Theory of Second Best, 34 Rev. Econ. Stud. 317 (1967). 
perfect vacuums and frictionless surfaces? The question answers itself. Science continuously postulates impossibilities in order to understand existing situations.

Now let the appropriate disclaimer be made. It is certainly true that, even using the elementary tools of orthodox economic theory, economists may disagree about the efficiency implications of economic phenomena, including business practices that come under the rubric of antitrust. ${ }^{79}$ And the disagreement cannot always be explained by the varying capability of scholars, although that no doubt accounts for part of it. Economics is not a laboratory science, and the use of its tools is not easily grasped. Yet when efficiency is compared with equity as a reference for antitrust policymaking, the virtue of efficiency is its relative objectivity. It is more likely that two economists will agree that a policy is efficient than that it is socially desirable on equity grounds.

Efficiency is the scientific linchpin of economics. It is closer to the concept of the atom in chemistry or energy in physics than to the political theorist's "state" or the theologian's "grace." Efficiency is itself valueless but, because it so directly promotes or prevents many social objectives, it is capable of securing normative admiration or disdain. While efficiency is objective in its nature, it is a phenomenon much admired by economists as normatively desirable. There was a period in recent United States intellectual history, roughly between 1955 and 1970, when it was fashionable to belittle efficiency as a social objective. Economizing was seen to be a minor problem given the abundance of goods and prospects for more. The oil shortage, the prospect of world famine, and the recent recession, more than economic reasoning, reminded the intelligentsia that resources, relative to wants, have been, are, and will continue to be scarce, and that consequently every society, whether composed of Sybarites or ascetics, should have a mechanism for using its resources at least somewhat efficiently.

Efficiency, however, is not to be pursued as the goal of goals. Quite the contrary. From the perspective of political economy, a viable competitive market system, appropriately seasoned with antitrust, is only a means, not an end. As my former colleague James M. Buchanan once stated: 
Law and legislation that is thoroughly informed by good economics will be based on an understanding of the market's function in maintaining social order, which is not primarily that of insuring efficiency, or maximizing value, as measured in market-determined prices. ... The market economy's socio-political function is that of minimizing the necessity of resorting to internal ethical constraints on human behavior and/or external legalgovernmental-political restrictions. ${ }^{80}$

\section{Conclusion}

The psalmist tells us that the Lord will judge with equity. ${ }^{81}$ With this in mind, one might hesitate to argue that in matters of antitrust the benchmark should be efficiency. Nevertheless, interspersing any equity considerations that conflict with efficiency into antitrust should be done with trepidation. Equity does not have the objective or predictive characteristics of efficiency. While it may seem tolerant, even humanitarian, to call for more equity at the expense of efficiency, those who do so seldom are the ones who suffer the loss in real wealth. This may make their call something that, in nontechnical jargon, economists call a cheap shot. Antitrust should take seriously its commitment to efficiency. Efficiency should not be absolute, to be sure, though each of us might place different values on particular tradeoffs. I would be willing to incur large losses in efficiency to protect the integrity of the family unit or to ensure religious freedom. Others have different normative objectives on which they would place great weight. No economist has yet argued that the course of genetic engineering or the use of electronic sensors should be determined only by the efficiency criterion of a disinterested competitive market mechanism. Yet those who begin by assuming that equity and efficiency are always mutually exclusive goals, and proceed to ponder the tradeoff, are mistaken. The congenial thing about antitrust is that the equity objectives that bear on its enforcement do not seriously conflict, and at times harmonize, with the pursuit of economic efficiency.

${ }^{80}$ Buchanan, Good Economics-Bad Law, 60 VA. L. Rev. 483, 486 (1974).

${ }^{81}$ Psalms 75:2. 